\title{
THE CONCEPT OF PEDAGOGICAL INFLUENCE ON THE RESEARCH POTENTIAL OF FUTURE PRIMARY SCHOOL TEACHERS IN TERTIARY EDUCATION
}

\section{Sushchenko L. $O$.}

\section{INTRODUCTION}

Today's dynamic development of civilization requires education system oriented towards new living standards and people's activities, since education has been an important factor in the development of a society. Whatever qualitative or quantitative changes occur in a society, educators remain the main figures in the process of producing new life values, supporting them with their innovative activities.

In the period of rapid globalization, high intellectualization, intensive growth of information, and radical transformation in the field of education, the urgent task of domestic professional pedagogy is as follows: appropriate strategic orientation of pedagogical professional training, formation of teaching framework taking into account long-term goals, implementing the model of sustainable and safe development, ensuring readiness of teachers to the new conditions of education and training, their efficient influence on the advanced harmonious development of educational and social environment.

In this regard, significant changes should be introduced into the existing system of professional training for future primary school teachers. Professional pedagogy needs a research aspect, in particular, it should focus on finding new alternative progressive ideas for the improvement and development of professional adaptation of future teachers to promising innovative concepts and technologies. It should stimulate the involvement of students in Professionally Oriented Research (hereinafter referred to as "POR"), so that they will be able to discover new teaching concepts and understand existing contradictions, gain experience in the formulation of hypotheses, independent scientific observations and planning, and conduct efficient professional research.

There are a lot of studies in domestic professional pedagogy which deal with the defining scientific approaches and the key principles of pedagogical influence on the overall development of student's 
personality in the context of research activity of students majoring in Primary Education (Specialty 013). But today an important and promising task is the optimal use of future teachers' research in order to bring them closer to the acquisition of professionalism in the process of training.

The analysis of a wide range of sources and scholarly works on the problem under study suggests that modern pedagogy covers only a few aspects of future teachers' research thoroughly. Thus, there is a need to create a holistic theory and methodology for primary school teachers' training in institutions of higher education. It involves certain significant transformations of the traditional system of research with regard to changes in educational priorities, appropriate modernization and updating of professional training process.

Science can go beyond the limits of certain historical practices and open up new subject worlds for humanity, which are destined to become the objects of practical development only in the future stages of civilization. It changes the system of existing ideas about educational process dramatically and sets the task of highlighting the priorities. In the new conditions the education system lags behind not because it is bad, but because it does not meet the needs of our time. Thus, there is a need to build a qualitatively new system with fundamentally new goals, tasks, and problems to be solved. A special place in the system of scientific knowledge is occupied by pedagogical studies, able to respond instantly even to the smallest changes in the present society.

Ukrainian scholars and researchers (teachers and psychologists, sociologists and defectologists, sociologists and culturologists) in response to the challenges of the time seek the conceptual foundations for the strategy of pedagogical advanced development, conducting research to ensure the formation of the very concept of "research activities", a new educational space, methodology of professional education taking into account the latest methodological principles.

It has been proved that reforms in the educational sphere in Ukraine, the contradictions between the requirements of scientific and technological progress and professional training stimulate the development of progressive ideas, critical reflection, creative retrospection of the accumulated experience in research practices in higher educational institutions. We suggest the concept of "students' research" should be defined through studying its historical roots on the 
basis of such concepts as "studies" and "pedagogical studies" that have been formed historically.

\section{Conceptual Approaches in the Training of Future Primary School Teachers: Psychological and Pedagogical Discourse}

Clear worldview and methodological principles give an opportunity to consider the peculiarities of concept "research" for future primary school teachers. This concept is based on philosophical, psychological and pedagogical studies of our predecessors, the experimental data they received and, which is of utmost importance, the analysis of their interconnection and interdependence.

Social and cultural globalization in the modern world, socio-cultural integrity, informatization and technological advancement in the human society put forward high demands for an individual, the main of which is maximum level of professionalism in pedagogical activity, which can be improved in the process of continuous education and is harmoniously combined with social responsibility.

This process results in the necessity of professional training of innovative thinking specialists - teachers-researchers, educatorsinventors, educators-scholars. The idea is closely linked to an increase of the importance of human factor in various spheres of social life, especially in the field of education. The demand for highly skilled, mobile, and competitive specialists, capable of continuous replenishment of personal scientific potential, is constantly growing.

"Concept" (from the Latin conseptio - understanding, system) in our study is understood as a system of principles and approaches that determine the strategy of research for future educators in higher education institutions. The concept of the study is to cover the leading idea of the research process as a holistic system, the core of which is the projection of theoretical principles on the future teacher's practical activities. But, in our opinion, one of the main challenges is to create a research conception and practices for future primary school teachers. We need a conception to provide new approaches to comprehension and generalization of research developing interrelations as an important mechanism for ensuring consistent pedagogical actions and decisions.

The concept of research for future teachers in higher education institutions (hereinafter - HEI) has been built on the basis of the following principles and approaches: 
- personality orientation of forms and means of education and upbringing (G. Ball, I. Bekh, I. Ziaziun, O. Pekhota, K. Rogers, V. Semychenko, et al.);

- systematic and integrated approaches to the study of personality in professional activity (B. Ananiev, N. Kuzmin);

- genesis of preparing a future teacher for research pedagogical activity (V. Andreiev, T. Vakolia, V. Zagviazynskyi, T. Klovak, T. Koicheva, M. Kniazian, S. Sysoieva, V. Slastionin, et al.);

- formation of professionalism, professional culture, professional skills, professional competence (V. Andrushchenko, N. Huzii, O. Hura, O. Dubaseniuk, I. Ziaziun, V. Mayboroda, et al.).

The organization of research activities for future primary school teachers (as a coherent, holistic, integrated and complex process) requires the integration of all the above-mentioned principles and approaches. All the principles, we base our study on, are interconnected.

Consequently, our concept of professionally oriented research activities suggests that pedagogical influence should also be complex, since the absolutisation of one single aspect can only interfere with the integrity of the process.

Thus, students' research activity cannot be efficient without individualization and differentiation as important factors for future teachers research. Personal orientation in this process is stimulated by natural human desire to reach "acme", i.e. the peaks of professional skills. The quintessence of professional skills is the acme aspiration, which cannot be realized without professional interactive space created. People themselves, their identity become a value, and this principle is central in the pedagogy of organization of the living space for future teachers. That is, there is a closed circle, a lot of interweaving, and therefore it is difficult to make a clear distinction between the spheres of influence of means, methods, and ways, characteristic of a particular approach in research practices.

Our study suggests that effective and efficient students' research can be demonstrated mostly by local practices of certain HEIs or innovation scholars and are considered rather an ideal, which is still not possible to achieve widely in educational system of Ukraine.

In our opinion, modern civilization is on the stage of laying foundations for the birth of a new philosophical educational paradigm, which can give a new framework for research organization as a 
mechanism for developing students' creative potential. For this stage of the development we have offered conceptual approaches to solve the problems.

The main ideas of the author's concept for future primary school teachers research are the following:

1. Professional training content for future teachers should be interactive at all stages and organizational levels. The goal of HEIs is to create preconditions for gaining and increasing intellectual and creative potential of students, acquiring new skills in their research activities.

2. Professionally oriented research in HEIs should be optimized with the aim of training a teacher-researcher of a qualitatively new type, able to apply various pedagogical technologies, with an innovative style of thinking, capable and ready to solve serious research tasks independently, purposeful, creative, dynamic teacher, who can demonstrate an original and highly effective approach to the solution of educational and training tasks, with a high level of responsibility and able to make a significant progress in professional activities. There is a need to create such a model of university education that will ensure the implementation of the principle of "learning through research", develop research skills, organize educational, cognitive and research activities of students, so that it contributes to mastery of methodological culture of teacher and researcher.

3. Future primary school teachers should be involved to research in order to bring them closer to professionalism. It is well known that efficiency of educational system as a whole depends on the level of teachers' professionalism and their training. The centre of educational process in HEIs is student's personality, and the development of student's identity in the process of creative and research activity is a determining factor in the formation of professionalism. Successful realization of these tasks requires understanding of teacher's objectives, i.e. what teachers should know to reach the heights of successful development of pedagogical skills, and to become as close as possible to the ideal reflection of essential spiritual nature in pedagogical process.

The suggested concept of research for future primary school teachers is based on a systematic approach to the study of pedagogical phenomena and processes that enables to ensure the effectiveness of students' educational, cognitive, and practical activity aimed at implementing personality oriented and performance oriented approaches. It promotes 
not only the formation of knowledge, skills and abilities, but also the development of pedagogical talents, creative thinking of future teachers, their intellectualization, encourages creative research.

Productive professional pedagogical training involves the achievement of maximum developmental effect aimed at the formation of the personality of future teachers and realization of their creative potential. Expansion of research into the area of professional activity of both teachers and students predetermines the fundamental need for rethinking all the factors that influence the process of organizing research activity in tertiary education. Thus, there is an urgent need for a highly qualified, competent teacher who would seek to master the methodology of research, acquire new research experience, find the possibility of self-realization in professional and pedagogical activities and implement theoretical knowledge into practice.

Taking into account the principles mentioned above, we determine the factors, essential for productive and effective organization of POR for future primary school teachers. First of all, one of the conceptual approaches can be seen in the creation of professionally oriented environment, which modern pedagogical studies consider in the context of humanitarian paradigm.

Theoretical and practical principles of educational environment relevant to the tasks of development and self-realization of the individual are analysed in the studies of I. Bekh, A. Verbytskyi, I. Yermakov, I. Ziaziun, O. Savchenko, S. Sysoieva, A. Sushchenko, T. Sushchenko, et al.

The term "environment" does not have a single unambiguous definition in modern science. In the wide sense, it is interpreted differently: as environment, system or conditions. In the narrow sense the term "environment" (micro-environment) means the immediate surrounding of a person.

Analysing the notion "educational environment", researchers emphasize that it should ensure all-round development of an individual and enable a person to realize his or her positive potential.

The process of the formation of future creative teacher, who would be engaged in research activity and organization in modern school, seems rather promising in the appropriate educational environment, which provides conditions for the development of research potential, academic mobility, and creative activity of students. 
A thorough analysis of psychopedagogical literature has proved that research of future educators is characterized by the creative orientation, it becomes more efficient when students learn to predict the result, formulate goals and hypotheses, look for independent ways to solve the tasks and objectives, substantiate the correctness of their decisions.

Along with the creation of such an environment, HEIs provide identification and implementation of mechanisms for internal and external interaction with other entities at all levels of education (school, higher education, pre-university and postgraduate education), state and nongovernmental organizations. The considered inter-university environment is a special form of academic community of professionals and future specialists; it functionally represents an analogue of a research school. Moreover, on the one hand, in the process of interaction of agents in such an environment new educational concepts are developed, educational technologies are tested; on the other hand - the environment contributes to personal and professional growth of its agents.

The high degree of objective complexity of this problem is determined by the influence of many factors on the overall result of professional educational activities. One of them is the creation of a fullyfledged professionally oriented environment, which broadens the field of manifestation of internal freedom and self-realization of the individual, raises the level of internal culture and at the same time modifies the direction, content, methods and nature of the process of research organizing. It is the reflexive organization of the latter that enables maximal realization of the positive potential of teachers and future specialists in mental, social, existential and spiritual growth, internally motivating their joint developmental interaction, provides the main humanistic principle of co-creation - achieving the integrity and increasing the diversity of spiritual and social life of each participant in educational interactions ${ }^{1}$.

Taking into account the abovementioned, we should conclude the following:

- future specialist chooses a particular paradigm in the conditions of a local professionally oriented environment through mastering pedagogical practices and academic communication in professional

${ }^{1}$ Бугерко Я. Рефлексивна сутність лонгітюдного інноваційно-психологічного експерименту з модульно-розвивального навчання. Психологія $і$ суспільство. 2011. № 3. C. $137-153$. 
circles, acquaintance with the latest achievements of scientific and technological progress and cultural development;

- the process of creating productive professionally oriented environment requires joint efforts and the involvement of HEI's teaching staff, its administration (managers of educational institutions, structural subdivisions), other specialists in the effective organization of students' research activity;

- productive professionally oriented environment determines the qualitative characteristics of the teaching staff, the construction and implementation of a system of the guidelines, since the interactive research of all participants in the educational process depends on them.

In the process of further implementation of these guidelines in the pedagogical process, an expansion of the spectrum of research forms for future teachers is expected; the orientation of the content of education to specialist model, which meets the criteria of quality; shifting goals towards the formation of interest in continuous professional selfimprovement and self-development.

Students' research activity should become a special point of bifurcation in the system of higher education, since it is the convergence of professional training with research, the desire for an integrated, interdisciplinary approach in solving set tasks, the search for new optimal ways and methods for improving the system of work with youth should be based on facilitation style of pedagogical interaction of teachers and students.

Given that pedagogical interaction depends entirely on the teacher's skills, the function of facilitation is important. It should create conditions for the development of pedagogical creative professionalism, or "psychological pedagogy" (according to K. Rogers), and assist in perceiving information and improving pedagogical interaction between teachers and students ${ }^{2}$.

That is, by promoting such interaction, teachers carry out facilitation support of mastering the basics of research methodology as a congruent component of professional training of future teachers.

Intensification of research depends on many factors, including on how effectively teachers organize the facilitative interaction between the

2 Левченко О. О. Людиноцентризм Карла Роджерса як концепція гуманізації професійної підготовки майбутніх викладачів психології. Освіта на Луганщині. 2010. № 2(33). С. 66-71. 
subjects of educational process, which involves the process of mutual spiritual enrichment of teachers and students in conditions of psychological comfortable relations, intellectual co-creation and flawless dialogic culture.

Such facilitative interaction is an integral part of the research process and represents a purposeful activity, which involves: desire for rapprochement and agreement among the participants; teachers' capacity to offer such form of life-creativity for students to capture their attentions, surprise and impress them; such an attitude towards students, which promotes their identity revealing, free communication and gradual development of future teacher's spiritual potential.

On the basis the ideas about personally oriented pedagogical process, we have identified the peculiarities of future teachers' research in the aspect of facilitative interaction of the subjects in educational space:

1. Efficient future primary school teachers' POR suggests that tutors should be rather guided by students' inclinations and desires than by formal programmes and plans.

2. POR is a process in which teachers' activities are organically combined with student's activities in a shared cognitive process.

3. Teachers should create conditions for self-development of students' internal forces and abilities by stimulating their thought processes.

4. Students should have flexible timetable, have a possibility to submit individual research projects before the deadline, conduct microresearch, etc., to have free time for other vital needs.

5. Such a process is practically invisible to a future specialist and requires special spiritual climate.

Thus, facilitative approach is considered means of implementing the strategy, which gives both students and teachers a chance to expand their horizons, and helps to see the problem in a new light. Such interaction can become a reliable basis for efficient educational and cognitive research activity of future teachers by setting up research, cognitive and practical tasks that require an independent creative decision. It requires psychological climate of trust, openness, benevolence, understanding of common or opposing issues. 


\section{Strategic Approaches to Future Primary School Teachers' Research Activity in Higher Education Institutions}

Given that socioeconomic changes encourage society to review the functions of modern teachers and their place in an updated educational system, each school needs an effective teacher with a high level of intellectual ability, who can guide and encourage students to attract their interest to learning and satisfy their intellectual curiosity.

Teaching and methodological source and programme coordinator for these purposeful changes should become a pedagogical university. Studying the problem of future teachers' professional training, we outlined its main aim as laying the foundations for gaining and increasing intellectual and creative potential of students, getting research experience focusing on professional training in the curricula.

The views of K. Ushynskyi and A. Makarenko have not lost their relevance in modern pedagogical training: teachers are highly educated people who love their profession, constantly improve their skills, have thorough practical training, are pedagogically tactful, humanistic, proficient in teaching and education, i.e. are not only good teachers, but good educators; know children's psychology, study pupils and know them well, aware of the new foundations of pedagogy and ground their activities on the advanced achievements of pedagogical studies ${ }^{3}$.

According to I. Ziaziun's theory, "teachers must be specialists to involve students to their studies, and scholars to develop their students' research skills. Teachers' personality attracts students with harmonious unity of ideals, beliefs, principles, views, hobbies, moral and ethical qualities, talent, love for their job, constant search for ways to improve pedagogical skills, attention to each student, the ability to develop skills of culture, to form personality ... In this case, a teacher is not just a "a translator of knowledge", but a holistic person who meets the high requirements for training of highly educated and harmoniously developed personalities ${ }^{4}$.

In modern American pedagogy there is a special term "efficient teachers". These people are distinguished by a unique combination of

${ }^{3}$ Ушинский К. Д. Избранные педагогические сочинения / Сост. В. Л. Струменский. Т. 2. М., 1954.

${ }^{4}$ Педагогічна майстерність в системі професійно-мистецьких компетентностей: зб. матеріалів IX Міжнародних педагогічно-мистеиьких читань nам'яті професора О. П. Рудницької / гол. ред.: І. А. Зязюн. Вип. 3(7). Чернівці : Зелена Буковина, 2011. 640 с. 
personal qualities and stable reaction, which are subjective prerequisites of professionalism in pedagogical work. For teachers' professional activity of great importance is so called "self-awareness", determined by the Ego-concept, which includes awareness of their physical, intellectual and other qualities, their own self-esteem, as well as the subjective perception of external factors.

"Efficient teachers" have a sense of self-confidence, consider themselves capable of overcoming life problems, have a high selfesteem. They are sure to overcome difficulties in their professional activity. The key feature of "efficient teachers" is their intention to succeed in class, despite any circumstances that may arise. School practice shows a small number of "efficient teachers". However, in the profession of a teacher, according to foreign specialists, most people can learn to act effectively. An important indicator of highly skilled pedagogical work is the desire for research technology, the need for constant updating and improvement of their knowledge, mastering modern methods of research activity. Teacher's role in the research process is to direct children to a deep, complex comprehension of a problem, creating conditions for independent research.

In our opinion, the training of a newly-educated teacher-educator becomes extremely important. We need a teacher who is capable and ready to solve serious research tasks independently, a teacher with original and highly effective approach to solving educational tasks.

Reflecting this way, we came to the conclusion that there is a steady need for implementation of the principle of "learning through research" via formation of research pool of knowledge and skills, organization of students' educational, cognitive and research activities, thereby contributing to mastering methodological culture by a teacher and researcher. Teachers are key figures of progressive transformations in education, especially they are researchers capable of changing, dynamic and flexible with constant need for continuous replenishment of their scientific potential.

Taking into account the potential of research activity in shaping the future teacher's personality in accordance with the requirements of the modern social labour market, one of the priority conceptual approaches, in our opinion, should be application of research activities as a mechanism for the development and implementation of creative potential for each student. 
It should be noted that conventionally in domestic high school there is a tendency to assess students' performance ignoring their potential. Consequently, the system of higher education is aimed primarily at reaching certain results, rather than on the development of future teachers' potential. It limits the impact of HEI on the development of the student's personality.

Research analysis shows that in modern studies the concept of "personality potential", as a collection of epistemological, creative, axiological, communicative and aesthetic potentials, has become popular. Thus, the formation and implementation of human potential is combined with different approaches to human activity and a variety of issues, including the development of the person's motivational sphere at different stages of ontogenesis.

Considering this problem in a holistic way, we can say that realization of the basic directions of professional education is possible provided the introduction and advanced organization of educational and research students' activities. This is due to the fact that in research process people first consider themselves subjects, and for the first time they face a problem of changing themselves as subjects. This process of development, the formation of a person as a subject is of conscious and purposeful nature.

In such conditions, research acquires the meaning of self-directed student's performance with activity component as its essential feature. Research organization deals with the management of this activity, i.e. its motivation, choice, and achievements, supporting peoples' success, their ability to perform certain actions in new conditions on the basis of previously acquired knowledge and skills, i.e. their background and expertise.

Advanced organization of the students' research activity, like any other activity, requires new, deeply thought-out, methodological approaches for its organization. Practice shows that lack of such organization has a negative influence, and even a long period of university study with its significant potential cannot provide training for future high school teachers to make them competitive in the world labour market.

Advanced students' research in the most general form covers obtaining sufficient information about the possibilities of choosing a sphere of activity, setting goals, time management, mastering the system of the most effective methods of self-organization, providing the necessary experience for the future, etc. 
Of utmost importance in the organization of POR for future primary school teachers is direct interaction of main structural subdivisions of POR - students and teachers of the department, which stimulates mutual creative enrichment. In this process, the leading role belongs to teachers, especially academic supervisors and tutors of the groups.

The best way to accomplish this task is to have an interest in research that promotes professional orientation of future teachers and determines their further self-realization as high-skilled specialists.

Cognitive interest, as a component of research, is closely connected with the formation of various personal relations: selective attitude to branches of study, cognitive activity, participation in the process and communication with the participants. A worldview, world perception, world awareness is formed on the basis of abovementioned phenomena. Student's cognitive interest, as evidenced in practice, largely depends on the competent approach and setting forth reasonable educational and research tasks. The interest in performing such tasks is not constant, it varies from year to year, with acquiring knowledge and skills of research. This interest also depends on the nature and content of academic disciplines, their teaching, it includes purely psychological qualities of the individual as well. A feature of cognitive interest is also its ability to enrich and intensify the process of not only cognitive, but also of any other activity.

At a certain stage of its development, the interest can evolve into the need of a higher order, i.e. the need for constant mastery of new knowledge. We fully agree with the opinion of H. Shchukina, who points out the following conditions for the development of the interest:

1. Active mental activity should provide maximum support. The main ground for the development of cognitive interest of students is active independent research and "discovery" of new knowledge, problem-solving.

2. Conducting educational process according to the level of students' development to reach gradual advancement of operational component of the study.

3. Favourable emotional class atmosphere.

4. Positive communication in the process of POR's organizing 5 .

5 Щукина Г. И. Проблемы познавательного интереса в педагогике. Г. И. Щукина. М., 1971. 331 с. 
Consequently, the development of future teachers' interest in research involves individual self-development for the purpose of advanced self-realization in favourable conditions. In other words, it is a cognitive need that ensures the orientation of future teacher's personality to realization of research goals and acquaintance with approaches and activities of future teacher-researcher. These activities are aimed at stimulating research ideas, creativity, mastery of new information that can contribute to a more complete and profound reflection of reality.

Our aim is to produce a consistent and logical definition, to analyse structural components of research conceptual model for future specialists. Although, it becomes obvious that it is impossible without a theoretical analysis of the ultimate goal of students' professional training, namely, their pedagogical professionalism.

Since professional self-development of the future teacher is understood as one of the complex forms of inner world activity on the path to self-realization and self-creation, we assume that attracting students to research can be successful through their professional training. This idea is a target benchmark in our study.

It is well known that the result of increasing efficiency of educational system as a whole depends on the level of teachers' professionalism and their training. How should the educational process be organized to put student's personality in the centre of professional training in HEI, taking for granted the fact that professionalism is highly influenced by personality's individual development in the process of creative research activity?

Before looking for the answer to this question, we want to clarify that one of the conditions for the realization of these tasks is training creative researchers aware of advanced methodology, able to combine the best tested practices and sustainable experience of teaching based on the latest scientific and technological achievements. Therefore, in our opinion, there are certain priorities that determine social need for training a professional educator of a new formation.

The aforementioned conceptual points outline approaches to research organizing for future educators as a purposeful conscious activity with certain potential intellectual values, which are the most powerful "self-driving force" in the development of professionalism.

From acmeological point of view, teachers' professionalism is the highest perfection in their pedagogical activities, the achievement of 
sustainable educational results through the creative use of optimal pedagogical technologies on the basis of self-actualization of subjects in pedagogical process. As part of the study of the problems of gaining professionalism, the following topical aspects have been considered: the basis of self-actualization of subjects in pedagogical process (O. Dubaseniuk, N. Kuzmina, A. Rean); model of specialist as a basis for professional training (N. Huziy); the ratio of personal and professional components in the process of gaining professionalization and in the structure of professionalism.

Professionalism of modern specialists is manifested in their high readiness to perform any kind of advanced activity, professional mobility, systematic professional growth and creativity.

As we have already noted, the central vector of the suggested conceptual model is identification of the efficient ways to organize research in HEIs. It is aimed at forming cognitive interest in pedagogical studies in the process of research activities for future teachers. Specifying our task in terms of theoretical solution, it should be mentioned, that research is one of the teachers' activities aimed at cognition and transformation of professional reality on the basis of achievements of pedagogical studies, application of advanced methods. The result of this activity is the acquisition of new pedagogical knowledge and experience, the development of methodological culture of teacher-researcher.

Relevance and significance of this approach is in the organization of training system, so that professional qualities are reasonably linked to the orientation towards the formation of future teachers' personality. As a result, teachers will be ready to make a contribution to positive changes in a particular professional environment.

It should be emphasized that teachers' professional activity is based on observation, analysis, construction and implementation of hypotheses, experiment, i.e. it is deeply creative. Creating and continually enriching of this activity with research skills is feasible and necessary. The path to such enrichment lies through the search and eliciting of the personal meaning in this purpose for each teacher, which requires the following research skills:

- ability to navigate in the flow of research findings;

- ability to evaluate and select alternative and elective programmes and create their own programmes on their basis; 
- ability to study promising, constantly developing teaching technologies;

- ability to study and apply effective pedagogical experience of other colleagues, etc.

Of particular importance is the experience of involving students in the organization of exciting and large-scale scientific research that are carried out on the principle of "vertical continuity" in the course of continuous education. In certain conditions future primary school teachers can benefit from these practices, participating in electoral institutions of full-fledged creative activity and development of individual talent, improvement of psychological health, relaxation of tension. They can give future teachers experience of real-life autonomy, practicing life roles, choice of life path, drafting personal plans and goals, acquisition experience in their implementation, and finally, the place of research self-realization.

That is, a modern school needs teachers with great personal potential and highly expressed research skills, who can find creatively solution to any professional task. We can conclude that POR's priority is an integral part of pedagogical professionalism. The organization of the research activities for future primary school teachers is aimed at:

1) creation of conditions for spiritual, intellectual, cultural and aesthetic self-development of students and young scholars' personality;

2) formation of each student's need for creative self-realization within the framework of quasi-professional research activity;

3 ) ensuring the students' learning methodology of cognition and creativity, the unity of intuitive-creative and discursive forms of cognition;

4) creation of prerequisites for the organic inclusion of future teachers in research activities;

5) mastering of future professional activity by students as a unity of theoretical training with the achievements of modern studies;

6) timely identification of creative potential, providing psychological and pedagogical support for gifted teachers.

\section{CONCLUSIONS}

As can be seen from the abovementioned, pedagogical professionalism is necessarily characterized by high performance productivity, which manifests itself at each of its main stages. In this 
case, highly productive activity is considered to be the ability to carry out pedagogical activities and to achieve success constantly through the implementation of the principle "learning through research", via formation of research skills in the educational process. We mean, primarily, the activity of no harmful health risk, the activity which brings satisfaction and develops true professional identity.

Based on these positions, we believe that involving future primary school teachers in research activities in order to bring them closer to professionalism means optimizing such experience:

- the task of a higher professional school is to train a researchers capable of applying their accumulated advanced potential and competences, perform their professional activities at a high level;

- stimulation of students to gain profound knowledge about the features of future professional activity by means of research;

- application and dissemination of the results and achievements of advanced research in order to create a desire for research, approach to profound cognition, collective and objective assessment of colleagues' successful achievements and practices in pedagogical activity;

- incorporation of research in future primary school teachers' professional training;

- priority orientation of future specialists on advanced developments, research and solving problems that have a direct connection with future professional activities;

- expanding the forms of creative activities, enriching them with new content by creating councils of young scientists, teams, societies, laboratories, innovative clubs, innovative students' associations in the field of natural sciences, humanities, social sciences and economics;

- interiorization of personal attitude of future primary school teachers to research activity.

Consequently, according to the author's conception, substantiated conceptual principles can only be implemented provided there are systematic, innovative changes in the system of education and training in modern pedagogical higher educational establishments. Mastering of future professional activities by students through research in combination with the need for creative self-realization within the framework of quasi-professional research are the main conditions for its efficiency. They lay foundations for the construction of our conceptual model of research organizing for future primary school teachers. 


\section{SUMMARY}

The concept of pedagogical influence on the process of research activities for future primary school teachers in higher education institutions is presented.

The emphasis is placed on the fact that a new methodological paradigm should contribute to the implementation of a new social and epistemological basis and lay foundations for the synthesis of theoretical and methodological, axiological and operational-technological aspects of educational theory and practice.

It is noted that an important conceptual idea of our advanced study is the idea that professional training will be efficient only on condition if both teachers and students are involved in research. Specialists whose training is carried out on the basis of the fundamental achievements of modern studies, able to conduct professionally oriented research and apply the results in practical activities will be competitive. Therefore, professional training of future primary school teachers should be based on the principles of professionally orientated research.

It is emphasized that qualitative renewal of education as a sphere of human development involves training of teachers bearing double responsibility: for children and their social life. These circumstances necessitate rethinking of methodological foundations for future teachers' professional training, where teachers are innovators and subjects (at the same time objects) of holistic pedagogical activity.

Proceeding from the defined conceptual points, we can outline the supra-task and the main direction of research - gaining professionalism by future teachers, their active involvement in research; acquiring important research practical experience; encouraging of in-depth study of future professional activity by means of research; study of pedagogical issues directly connected with future professional activity; interiorization of future teachers' personal attitudes to research.

\section{REFERENCES}

1. Бугерко Я. Рефлексивна сутність лонгітюдного інноваційнопсихологічного експерименту з модульно-розвивального навчання. Психологія і суспільство. 2011. № 3. С. 137-153.

2. Левченко О. О. Людиноцентризм Карла Роджерса як концепція гуманізації професійної підготовки майбутніх викладачів психології. Освіта на Луганщині. 2010. № 2(33). С. 66-71. 
3. Ушинский К. Д. Избранные педагогические сочинения / Сост. В. Л. Струменский. Т. 2. М., 1954.

4. Педагогічна майстерність в системі професійно-мистецьких компетентностей: зб. матеріалів IX Міжнародних педагогічномистецьких читань пам'яті професора О. П. Руднищької / гол. ред.: I. А. Зязюн. Вип. 3(7). Чернівці : Зелена Буковина, 2011. 640 с.

5. Щукина Г. И. Проблемы познавательного интереса в педагогике. Г. И. Щукина. М., 1971. 331 с.

\section{Information about the author: Sushchenko L. 0.}

Doctor of Education, Associate Professor, Professor of the Department of Education and Management

Educational Institution, Classic Private University 70-b, Zhukovskoho str., Zaporizhzhia, 69002, Ukraine 